\title{
SIMULTANEOUS ESTIMATION OF PARACETAMOL AND ETODOLAC BY HPLC METHOD IN PURE AND COMBINATION FORMULATION
}

\author{
R. Vijayalakshmi` and VSH. Naveena \\ Research lab, GIET School of Pharmacy, NH-16, \\ Chaitanya Knowledge city, Rajahmundry-53 3296, Andhra Pradesh, India.
}

\begin{abstract}
Paracetamol and Etodolac are non- steroidal anti-inflammatory drugs with analgesic and antipyretic properties, was determined by a new RP-HPLC method. The method was developed on aphenomenex $\mathrm{C} 18(4.6 \times 250 \mathrm{~mm}, 5 \mu$ i.d) column, aided by a mobile phase mixture ofmethanol and phosphate buffer of $\mathrm{pH} \mathrm{6.8,} \mathrm{in} \mathrm{the} \mathrm{ratio} 80: 20 \%, \mathrm{v} / \mathrm{vat}$ a flow rate of $1.0 \mathrm{~mL} / \mathrm{min}$ and monitored at $231 \mathrm{~nm}$. Retention time of about $4.89 \mathrm{~min}$ and $3.79 \mathrm{~min}$ was observed for paracetamol and etodolac, respectively. Linearity showed good correlation close to 1 for both the drugs in a range of $200-700 \mu \mathrm{g} / \mathrm{ml}$ for paracetamol and $0.5-3 \mathrm{mg} / \mathrm{ml}$ for etodolac.The LOD and LOQ values were found to be 19.14 and $58 \mu \mathrm{g} / \mathrm{mL}$ for paracetamol and 3.089 and $9.3 \mu \mathrm{g} / \mathrm{mL}$ for etodolac, respectively. The proposed method was demonstrated to be most accurate, precise, specific, and robust which was found to be useful for routine analysis.
\end{abstract}

Keywords: Paracetamol, Etodolac, HPLC and binary mixture.

\section{INTRODUCTION}

Paracetamol $^{1}$ is chemically $\mathrm{N}$-(4hydroxyphenyl) acetamide and Etodolac ${ }^{2,3}$ is chemically $\quad 1, \quad 8$ diethyl-1,3,4,9tetrahydropyrano[3, 4-b] indole-1-acetic acid. Both these drugs belong to class of nonsteroidal anti-inflammatory drugs (NSAIDs). Literature survey revealed that only few LC, spectrophotometric methods for the estimation of paracetamol and etodolac ${ }^{4-8}$ in tablet dosage forms are available. In this present study RPHPLC method was developed for the simultaneous estimation and validation of paracetamol and etodolac in pure and combination formulation.

\section{EXPERIMENTAL}

\section{Equipment}

SHIMADZU LC 20AD system with SPD-20A UV/VIS detector equipped with Spinchrom software was used for method development, double-beam Perkin Elmer (LAMBDA 25) UVVIS spectrophotometer was used for spectral measurements and ELICO $\mathrm{pH}$ meter for $\mathrm{pH}$ measurements.

\section{Reagents and pharmaceutical preparations} Gift samples of Paracetamol and Etodolac presented by Aurobindopharma Ltd, Hyd, were used as standards without further purification. Water, methanol (HPLC grade, Rankem), potassium dihydrogenortho phosphate, sodium hydroxide (A.R grade, Rankem) were used in the analysis.

\section{Preparation of Buffer (pH-6.8)}

$125 \mathrm{ml}$ of $0.2 \mathrm{M} \mathrm{KH}_{2} \mathrm{PO}_{4}$ was taken in a $500 \mathrm{ml}$ volumetric flask, $56 \mathrm{ml}$ of $0.2 \mathrm{M} \mathrm{NaOH}$ was added and finally made upto the volume with HPLC grade water.

Methanol and phosphate buffer $\mathrm{pH} 6.8$ $(20: 80 \% \mathrm{v} / \mathrm{v})$ were filtered through $0.45 \mu \mathrm{m}$ membrane filter and degassed for further use.

\section{Chromatographic conditions}


The method was developed with a mobile phase of methanol:buffer of $\mathrm{pH} 6.8$ in the ratio of $80: 20 \mathrm{v} / \mathrm{v}$ and at a flow rate of $1 \mathrm{ml} / \mathrm{min}$. The detection was monitored at $231 \mathrm{~nm}$ and at ambient temperatures.

\section{METHOD OPTIMIZATION}

The separation was achieved on a Phenomenex $\mathrm{C}_{18}(250 \mathrm{~mm} \times 4.6 \mathrm{~mm}, 5 \mu)$ column based on the polarity of the drug. Mobile phase was selected after several trials with acetonitrile, methanol and buffers of various $\mathrm{pH}$ of $6,6.8,7$ and 7.2. Phosphate buffer with $\mathrm{pH}-6.8$ and methanol were showing lower retention time and good peak shape without tailing. Composition of mobile phase mixture, flow rate and the detection was monitored at $231 \mathrm{~nm}$. Results were depicted in table-1.

\section{METHOD VALIDATION}

The method was validated for accuracy, precision, linearity, LOD, LOQ, ruggedness and robustness and the results were found to be satisfactory. Regression parameters were presented in table 1.

\section{Linearity and range}

Linearity was assessed by performing single measurement at several analyte concentrations of paracetamol and etodolac injected at an interval of $10 \mathrm{~min}$ and showed good correlation between concentration range of $200-700 \mu \mathrm{g} / \mathrm{ml}$ for paracetamol and 0.5 $3 \mathrm{mg} / \mathrm{ml}$ for etodolac. The results were produced in table 2 and table 3 and pictured in fig 1 and fig 2.

\section{Accuracy}

The recovery studies yielded the mean results within $98-102 \%$ of true concentration of each drug indicating that the test method has an acceptable level of accuracy and the results were presented in table 4.

\section{Precision}

Five replicate injections of working standard solutions have been studied for system precision and method precision and the results were presented in table- 5 indicating reproducibility of the method.

\section{Robustness}

Robustness was checked by altering the optimized parameters and the \%RSD was found to be $<2$ i.e within acceptable limit. And the results were given in table 1 .

\section{Ruggedness}

System to system/ analyst to analyst/ column to column variability study was conducted on different HPLC systems, different columns and different analysts under similar conditions at different times and the results were shown in table 1.

\begin{abstract}
Limit of detection (LOD) and limit of quantification (LOQ)

LOD AND LOQ were determined by analyzing progressively lower concentrations of the standard solutions using optimized chromatographic conditions and the results were found to be satisfactory and were presented in table 1.
\end{abstract}

\section{CONCLUSION}

The proposed RP-HPLC method for estimation of paracetamol and etodolac in tablet dosage method was more accurate, simple, efficient and the results were found to be satisfactory with retention time $<7 \mathrm{~min}$, so the method is not time consuming and can easily applied for routine laboratory analysis.

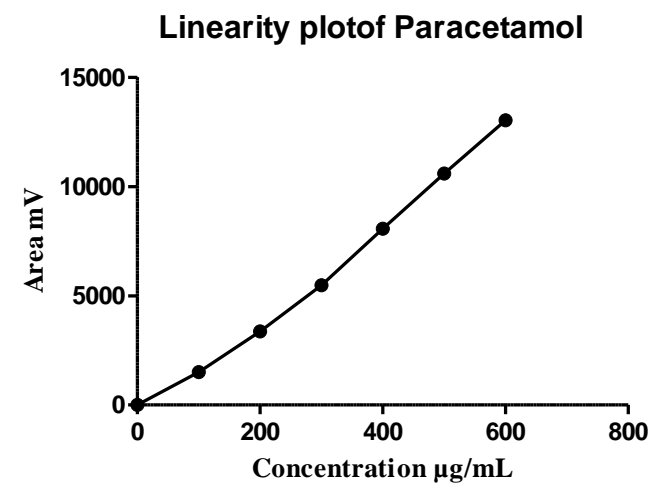

Fig. 1: Linearity plot of Paracetamol 


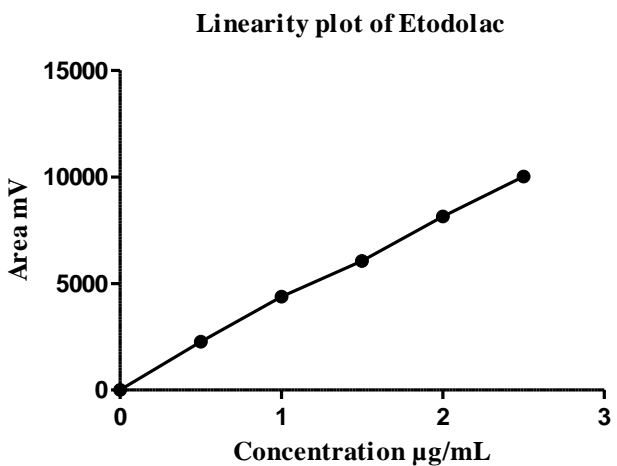

Fig. 2: Linearity plot of Etodolac

Table 1: Optical and regression parameters

\begin{tabular}{|c|c|c|}
\hline PARAMETER & PARACETAMOL & ETODOLAC \\
\hline Theoretical plates & 11842.22 & 11769.12 \\
\hline Retention time, min & 4.897 & 3.797 \\
\hline Correlation coefficient & 0.9996 & 0.998 \\
\hline$\% R S D$ & 0.22 & 0.79 \\
\hline LOD, $\mathrm{mcg} / \mathrm{ml}$ & 19.14 & 3.089 \\
\hline LOQ, $\mathrm{mcg} / \mathrm{ml}$ & 58 & 9.3 \\
\hline Tailing factor & 0.08 & 0.06 \\
\hline Linearity range & $200-700 \mu \mathrm{g} / \mathrm{ml}$ & $0.5-3 \mathrm{mg} / \mathrm{ml}$ \\
\hline
\end{tabular}

Table 2: Linearity

of Paracetamol

\begin{tabular}{|c|c|}
\hline Conc., $\mathbf{\mu g} / \mathbf{m L}$ & $\begin{array}{c}\text { Area, } \\
\mathbf{M v}\end{array}$ \\
\hline 100 & 1502.0 \\
\hline 200 & 3372.5 \\
\hline 300 & 5487.0 \\
\hline 400 & 8073.0 \\
\hline 500 & 10589.0 \\
\hline 600 & 13032.0 \\
\hline
\end{tabular}

Table 3: Linearity of Etodolac

\begin{tabular}{|c|c|}
\hline Conc., $\boldsymbol{\mu g} / \mathbf{m L}$ & $\begin{array}{c}\text { Area, } \\
\mathbf{m v}\end{array}$ \\
\hline 0.5 & 2263.9 \\
\hline 1.0 & 4382.1 \\
\hline 1.5 & 6052.5 \\
\hline 2.0 & 8137.6 \\
\hline 2.5 & 10012.7 \\
\hline
\end{tabular}

Table 4: Recovery studies of Paracetamol and Etodolac

\begin{tabular}{|c|c|c|c|c|c|}
\hline \multicolumn{2}{|c|}{ Concentration added, \% } & \multicolumn{1}{c|}{ Percentage recovered ${ }^{*}$} & \multicolumn{2}{c|}{$\%$ RSD $^{*}$} \\
\hline PCM & ETD & PCM & ETD & PCM & ETD \\
\hline 50 & 80 & 99.17 & 98.3 & 0.7 & 0.9 \\
\hline 100 & 100 & 99.85 & 99.9 & 0.7 & 0.7 \\
\hline 150 & 120 & 99.78 & 99.6 & 0.6 & 0.7 \\
\hline
\end{tabular}


Table 5: Precision studies of Paraceamol and Etodolac

\begin{tabular}{|c|c|c|c|c|c|c|c|}
\hline \multirow{2}{*}{ Parameter } & \multirow{2}{*}{ Conc, \% } & \multicolumn{2}{|c|}{ Mean Peak area } & \multicolumn{2}{c|}{ SD } & \multicolumn{2}{c|}{$\%$, RSD } \\
\cline { 3 - 8 } & & PCM & ETD & PCM & ETD & PCM & ETD \\
\hline System Pression $^{\star}$ & 100 & 10374 & 7459.2 & 6.63325 & 7.628 & 0.063 & 0.10 \\
\hline Method Pression $^{\star}$ & 100 & 99.3 & 99.1 & 0.7 & 0.8 & 0.765 & 0.80 \\
\hline
\end{tabular}

${ }^{\star}$ Mean of six replicates

\section{REFERENCES}

1. United State Pharmacopoeia 2007. 30thed. Rockville: USP Convention, INC. 2007;2129-2131.

2. Indian Pharmacopoeia 1996. New Delhi: The Controller of Publications. Govt. of India; 1996. 554.

3. British Pharmacopoeia 1998. London: Her Majesty's Stationary Office. 1998; 1854 .

4. Balan P, Carolin NI, Lakshmi PM, Vanaja RM and Rajasekar S. RPHPLC Method Development and Validation of Etodolac and Paracetamol in Combined Dosage Form. Asian $J$ Res Chem. 2011;4(7):1073-1076.

5. Sruthi A, Thanuja N, Sai Samhita M, Sudheer Kumar D and Sreekanth G. A Simple RP-HPLC Method for Simultaneous Estimation of Paracetamol and Etodolac in Tablet Dosage Form. Indo American J Pharm Res. 2013;3(5):3742-3751.
6. Siva Rama Krishna V, Sateesh B and Ravi NT. RP- HPLC method development and validation of Etodolac and Paracetamol in tablet dosage form. Int $\mathrm{J}$ Pharm Tech Res. 2014; 6(2):775-782.

7. Balan P, Carolin NI, Lakshmi PM, Vanaja RM and Rajasekar S. Simultaneous Estimation of Etodolac and Paracetamol by UV spectrophotometric method in tablet formulation, Journal of Pharmacy Research. 2011;4(6):1663- 1665.

8. AmeenShaikh, Gurdeep Singh, Neetesh K Jain and Gupta MK. Development and validation of new simple, sensitive and validated UVspectrophotometric and RP-HPLC method for the simultaneous estimation of paracetamol and etodolac in marketed formulation. $\mathrm{J}$ Drug DelivTher. 2017;7(4):120-124. 